\title{
RECENZE
}

\section{Hledání intuitivní ženské chytrosti v jádru tradic antického modelu výchovy}

\section{Kryštof Boháček}

Recenzovaná monografie: Hawhee, D., 2004, Bodily Arts: Rhetoric and Athletics in Ancient Greece, Austin.

Kniha Debry Hawhee je pěknou ukázkou amerického multidisciplinárního př́stupu posledních desetiletí: položíme-li si otázku, do jakého oboru vlastně náleží, budeme na rozpacích: mohli bychom ji zařadit stejně tak do dějin filosofie jako do teorie komposice textu, klasicko-filologického žánru, do ženských studií, rétoriky, teorií kultury antropologického či historicko-sociologického střihu etc. Autorka sama je dnes $\mathrm{v}$ zahraničí poměrně známou a citovanou osobností díky své slavné a již mnohokrát reeditované učebnici Ancient Rhetoric for Contemporary Students (1994, 1999, 2004, spoluautorka Sharon Crowly).

Bodily Arts je pozoruhodná práce, sestávající z většího počtu separátních detailních zkoumání určitých typických rysů antické kultury, vzdělanosti a vůbec základního antického postoje ke světu, v jejichž jádru ovšem autorka zdůrazňuje aspekty běžně chápané jako spíše marginální. Autorka to zdůvodňuje všeobecným 
upřednostňováním racionality a abstraktního myšlení v rámci klasických studií a zejména filosofie.

Cílem Hawheeové je syntézou zmíněných separátních analýz dojít $\mathrm{k}$ celkově odlišnému obrazu antické kultury. Obrazu, v němž sice všechna typická témata klasických studií mají své místo, v němž nicméně hlavní, tvůrčí a hybnou roli hraje jeden základní proud, který autorka nazývá „tělesnou moudrostí“ či způsobem myšlení, který je fixován na tělo a vnímání, z těla a jeho situativnosti a vždy vychází a vše k němu vztahuje.

Kniha sestává ze sedmi kapitol. V první autorka reinterpretuje klasický koncept areté ve vztahu k agonálni povaze řecké kultury tak, aby vynikla původní dynamická povaha areté: je ji třeba osvědčovat zápasem tváří v tváŕ výzvám. Tomu ve druhé kapitole odpovídá koncept métis, sofistické vychytralosti či odysseovské kontextuální 1stivosti, zjevně alternativní vůči statické sofiá.

Třetí kapitola zkoumá koncept kairos v nejširších souvislostech, a snaží se nalézt jeho prapůvod v situovanosti těla a jeho nutnosti přizpůsobivě reagovat na prostředí.

Čtvrtá, pátá a šestá kapitola jsou věnovány různým aspektům konceptu sebekonstrukce v procesu klasické attické výchovy. Východiskem je opět detailní analýza atletických tréninkových metod od nejstarších dokladů, výklad postupuje přes topologii archaického a klasického gymnasia a uzavírá zkoumáním role rytmu a hudby v záměrném procesu sebeutváření jak jedince, tak celé řecké kultury. 
Paralelně s atletickým výcvikem je samozřejmě zkoumána výchova sofistů a filosofů, která podle autorky vrcholí rétorickou syntézou v raně hellénistické době. Veškerá intelektuální stránka výchovy nicméně $v$ rámci tradice následuje až za utvářením těla, je traktována skrze atletickou terminologii a determinována tělesnými metaforami. Poslední kapitola je tedy věnována převzetí vedení filosofií a rétorikou na úkor atletického tradičního základu.

Hawheeové kniha je neobyčejně inspirativní, zvláště v českém prostředí, kde stále některé běžně zavedené rétorické koncepty a způsoby traktování vyvolávají kontroverze. Autorka nicméně nezapře svůj „,̌̌enský hlas“ a přespř́iliš násilně se snaží všude dosadit jediný aspekt, kterým je jakýsi odlišný druh moudrosti či myšlení, zjevně evokující ženskou empatii, sociální inteligenci a manipulativní chytrost na úkor (mužského) abstraktního myšlení. Ve výkladu kultury, pro kterou ženy prakticky neexistují, to působí nepřirozeně. 